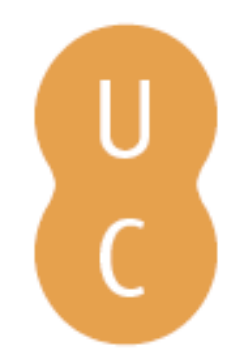

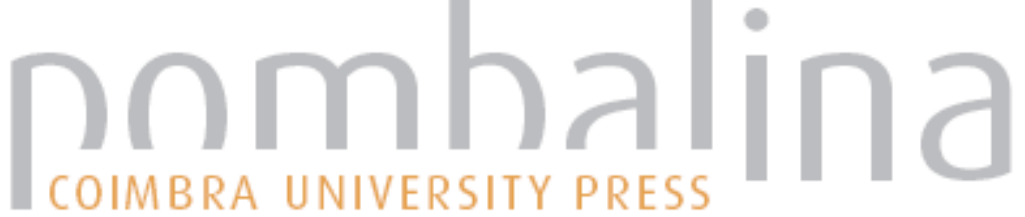

\section{Le Corbusier: a modern monk}

\section{Autor(es): Leatherbarrow, David}

Publicado por: Imprensa da Universidade de Coimbra

URL persistente:

URI:http://hdl.handle.net/10316.2/41607

DOI:

DOI:https://doi.org/10.14195/978-989-26-1338-3_4

Accessed : $\quad$ 26-Apr-2023 11:05:42

A navegação consulta e descarregamento dos títulos inseridos nas Bibliotecas Digitais UC Digitalis, UC Pombalina e UC Impactum, pressupõem a aceitação plena e sem reservas dos Termos e Condições de Uso destas Bibliotecas Digitais, disponíveis em https://digitalis.uc.pt/pt-pt/termos.

Conforme exposto nos referidos Termos e Condições de Uso, o descarregamento de títulos de acesso restrito requer uma licença válida de autorização devendo o utilizador aceder ao(s) documento(s) a partir de um endereço de IP da instituição detentora da supramencionada licença.

Ao utilizador é apenas permitido o descarregamento para uso pessoal, pelo que o emprego do(s) título(s) descarregado(s) para outro fim, designadamente comercial, carece de autorização do respetivo autor ou editor da obra.

Na medida em que todas as obras da UC Digitalis se encontram protegidas pelo Código do Direito de Autor e Direitos Conexos e demais legislação aplicável, toda a cópia, parcial ou total, deste documento, nos casos em que é legalmente admitida, deverá conter ou fazer-se acompanhar por este aviso. 
Ivan Zaknic

Arthur Rüegg

David Leatherbarrow

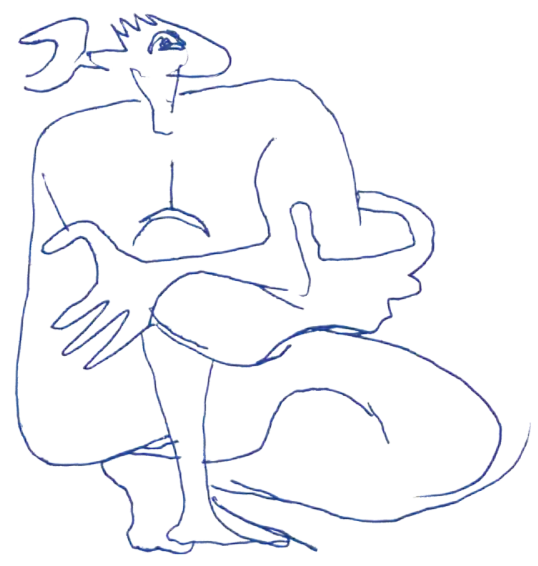

Christoph Schnoor

Francesco Passanti

Johan Linton

Stanislaus von Moos

Maria Candela Suárez

\section{Le Gorbusier}

\section{HISTORY TRADITION}

Edited by

Armando Rabaça 


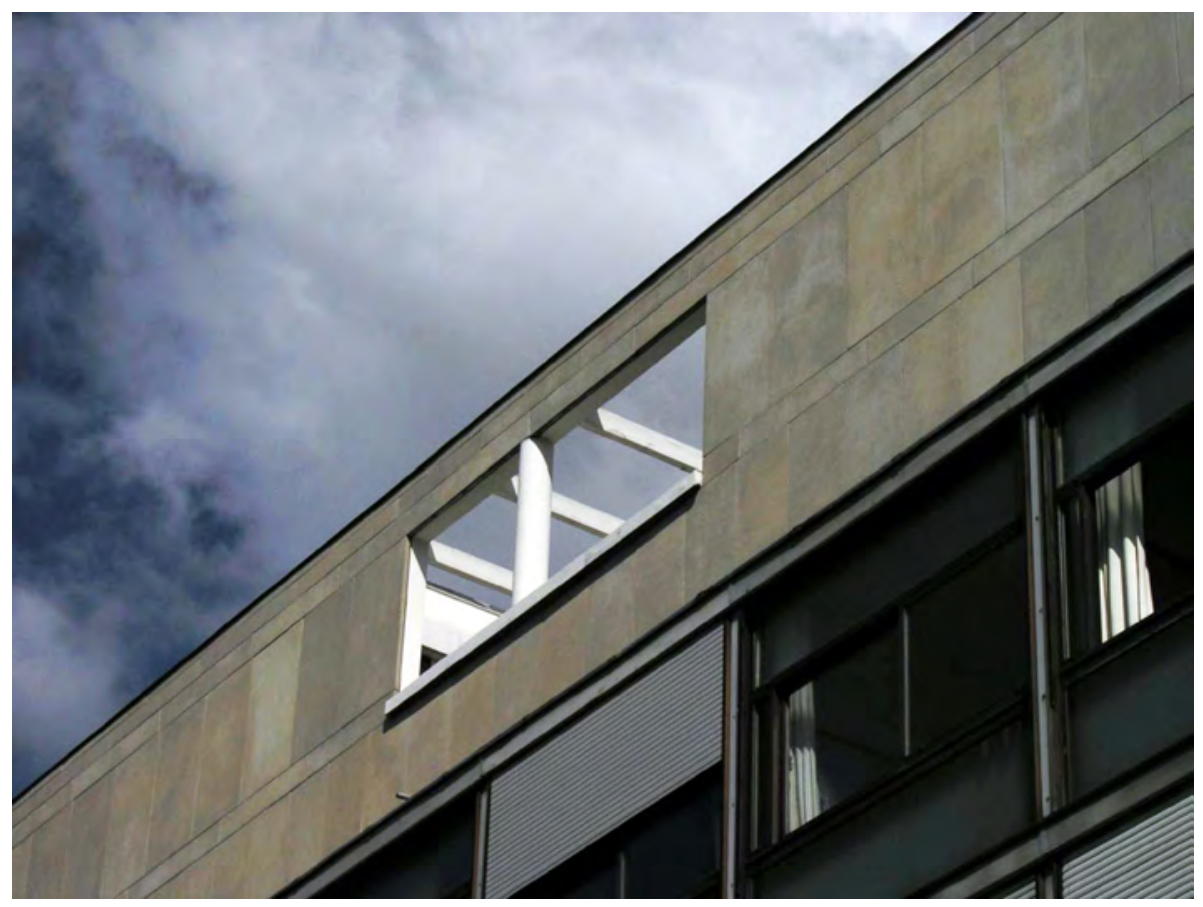

1. Swiss Pavilion, Paris, 1930-32.

Upper level window view. 


\section{Le Corbusier: a Modern Monk}

... devoting yourself to architecture is like entering a religious order.

Le Corbusier Talks With Students. ${ }^{1}$

For Le Corbusier, moving forward in time, out of the recent past into the modern world, was often preceded by movement in backward in time, toward some earlier period, often much earlier, an age of radical beginnings, mythical though they often were. Even though recursive movements were hardly modern, in the progressive sense of the word, it was indeed to the past that Le Corbusier regularly turned in his projects, art works, and writings, despite his no less common advocacy of l'Esprit Nouveau. The facts speak for themselves, and do so more loudly than the strident assertions of the apologists who announced a fully emancipated modernism, as did some of the movement's protagonists.

The instance of Le Corbusier's historically-grounded-modernism to be addressed in this study is his lifelong preoccupation with monastic culture and its reinterpretation in the modern period, the monastic tradition one could say, even if the history that animated its chronology was discontinuous and its several manifestations alternately sacred and secular. ${ }^{2}$

Rather than pursue this opening consideration of Le Corbusier's modernity in broad and inclusive terms, I shall start with what might 
seem a rather minor issue in one of his projects: his strong - though not completely successful - resistance to the suggestion that he open a window in the upper level of the façade of the Swiss Pavilion in Paris' Cité Universitaire. That this little controversy bears on the question concerning his monastic vision of living in the modern world should be apparent in the following two quotations, neither of which was, however, offered in defense of his stance concerning the Swiss Pavilion window:

What the student wants is a monk's cell, well lit and well heated, with a corner to gaze at the stars. ${ }^{3}$

monks' cells ... secret gardens ... an infinity of landscape ... a tete-à-tete with oneself. A sensation of extraordinary harmony comes over me. ${ }^{4}$

\section{STUDENT MONKS}

It was not just one student's room that Le Corbusier refused to illuminate through an opening in the upper level or fascia of the south façade of his Pavillon Suisse, but rooms for five. ${ }^{5}$ The request came as a result of a midproject increase in the number of students to be accommodated in the building, from forty-five to fifty. ${ }^{6}$ Because the design of the lower three levels of student rooms had been fixed (an enfilade of fifteen rooms per floor) there was no place to locate the additional rooms other than the roof level, which had been initially planned to accommodate (and inwardly orient) a range of non-residential settings: rooms for physical exercise, a space for music, and a small ensemble of study rooms, including a library. There was also to be a small shared garden (in some phases of the project it was called the solarium), and the director's rooms, together with those allotted to the domestic help. 
Here's the problem: throughout the entire history of the project these settings were largely hidden behind the fascia, open only the enclosed garden court, and thus to the sky (Fig. 1). ${ }^{7}$ This last condition was, of course, imagined to be no small pleasure, as indicated in the first quotation above. Le Corbusier's resistance to the suggestion that windows could be "easily opened" in the façade's upper surface was a matter of principle, or perhaps one should say of principles, for when he explained himself in detail it became clear that many issues were in play, partly aesthetic and partly cultural - the culture of the student-monk.

First, there was the matter of visual harmony. Were he to extend the floor-to-ceiling glazing (window walls) of the three lower levels up to the fourth a great "obstacle" would have appeared: "architecturally, the façade would become inordinately high [he argued]. . . our building would be out of scale." More specifically, he maintained it was a question of the "harmony" of scale (Fig. 2). With this basic principle of architectural order at risk, the question about change was answered with a resounding no: "We hesitate no longer: the rooms shall open behind the fascia, onto small gardens ... here [on the front face] it is the proportion that counts."

He sought to secure a second point in defense against any accusation of insufficiency - insufficient light, air and view for the roof-level roomswhich would have been, ironically, the sort of criticism he himself would have leveled against recent architectures. It was at precisely this point in the controversy that the matter of tradition came into focus, for he buttressed his argument with references to much earlier examples of student room or cell design: "during our educational travels, we often appreciated . . . just such an architectural device [a room's aperture onto "the serenity of" a small garden] within the famous monasteries! And we are therefore convinced that these five rooms will be the most beautiful within the entire pavilion." Even for a writer prone to overstatement, this claim about windowless rooms being the most beautiful in the building comes as something of a surprise.

The travels to which he referred were visits to Carthusian monasteries. The encounter he mentioned most frequently was with the Certosa di 
Le Gorbusier: A Modern Monk

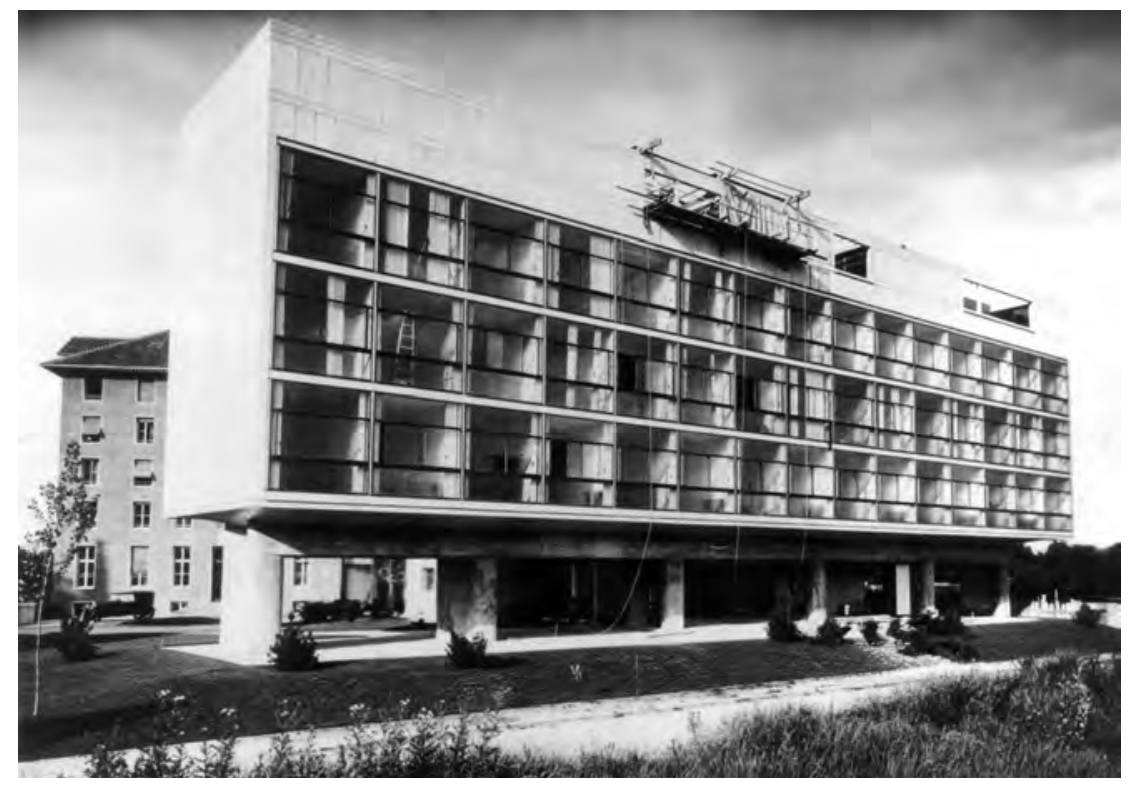

2. Swiss Pavilion, Paris, 1930-32.

Façade view. 
Firenze, which he called Ema (Figs. 3, 4). ${ }^{10}$ Among the repeated references, the following from his book Precisions may be the most helpful when trying to understand the claim about the Swiss pavilion's roof-top rooms:

The beginning of these studies [of dwelling at a human scale], for me, goes back to my visit to the Carthusian monastery of Ema near Florence, in 1907. In the musical landscape of Tuscany I saw a modern city crowning a hill. The noblest silhouette in the landscape, an uninterrupted crown of monks' cells; each cell has a view on the plain, and opens on a lower level on an entirely closed garden. I thought I had never seen such a happy interpretation of a dwelling. The back of each cell opens by a door and a wicket on a circular street. This street is covered by an arcade: the cloister. Through this way the monastery services operate- prayer, visits, food, funerals. ${ }^{11}$

There are a number of useful points in this quotation. The first is that the monk - who would be a student in the Swiss Pavilion — had a view that opened onto an entirely enclosed garden (forgetting for a moment the additional view onto the plain). Although one imagines such a view would have given the monk some pleasure, and perhaps been an aid to the contemplative life, the garden was also a work place. Some Carthusian brothers planted vegetables in these gardens, others transformed them into work yards, where they undertook carpentry and other manufacturing or repair activities. Students in the Swiss Pavilion, however, would have exercised themselves in the little gymnasium on the roof, or the sports fields nearby. The second useful point in Le Corbusier's defense of his garden-facing cells is that he had never seen, and presumably couldn't imagine an interpretation of dwelling that was happier. Solitary contemplation (serenity) was perfectly sheltered in settings of this kind, also some measure of self-sufficiency. In another allusion to the monastery at Ema he wrote:

In early youth I travelled to Italy, the Balkans, Constantinople, Orient. The idea of homes repeated and grouped in units struck me in the monastery of Ema in 
Le Gorbusier: A Modern Monk

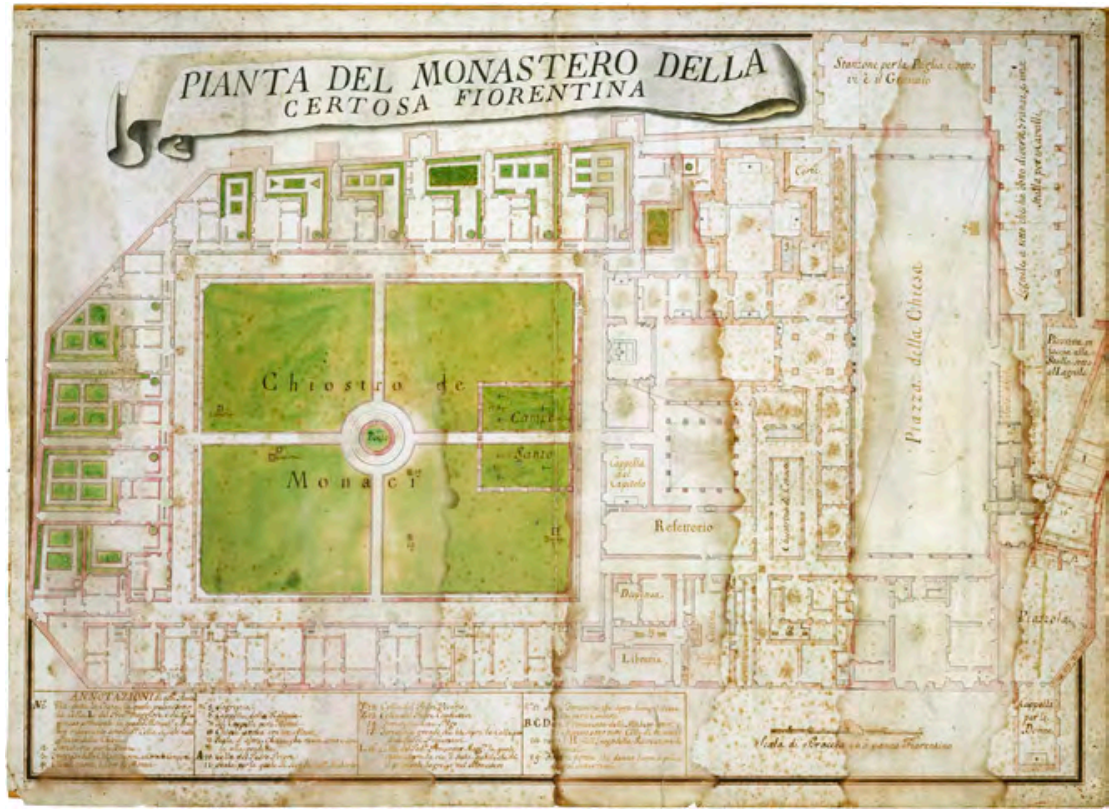

3. Charterhouse, Galluzzo, Florence. Plan. 


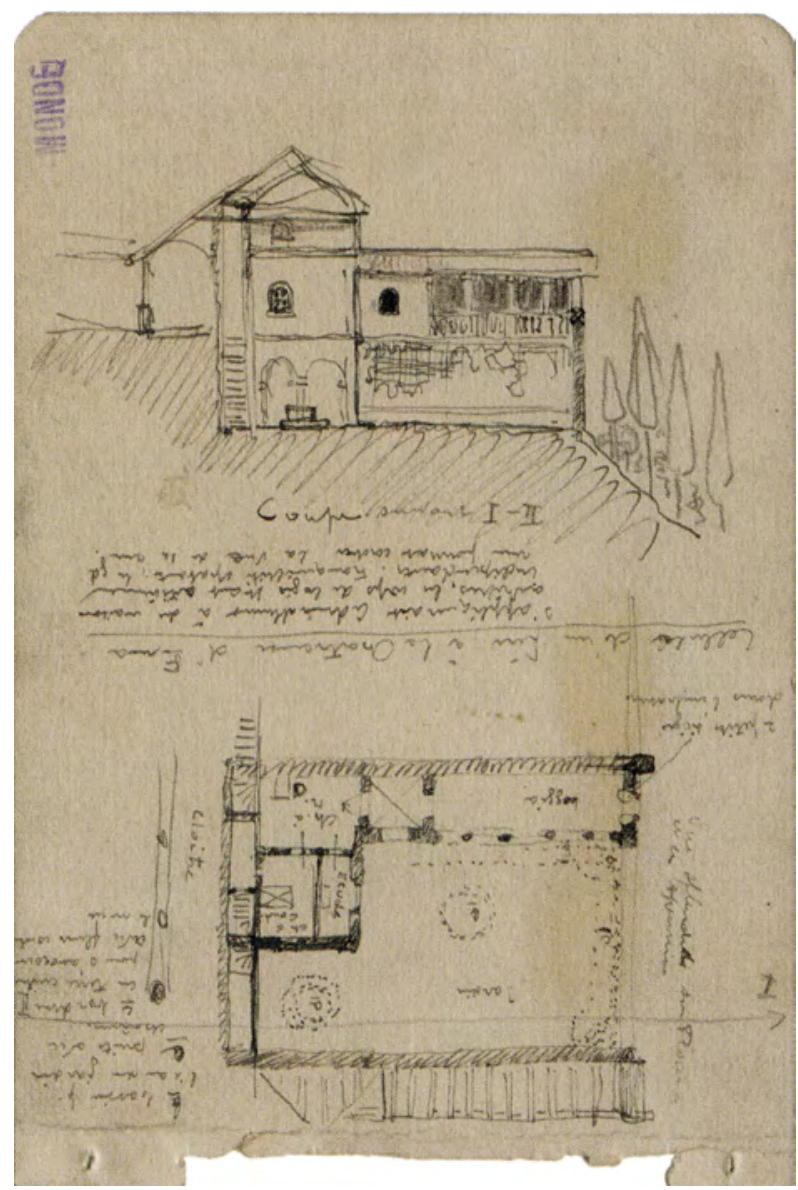

4. Le Corbusier.

Sketch of the Certosa di Firenze. Cell plan and section, 1907. 
Tuscany. Look, I still have with me a notebook in which I sketched the abode of monks ... Everyone has what they need, that is to say little, if they are wise. One who is still battered by the instinct of possession can buy an apartment, a house, if you will. But real estate can and should belong to everyone: clean air, the sun, the view of nature, walking in the orchard, games and many other things. What do I need to own? Several books? Probably. But are there not thousands at the National Library? ${ }^{12}$

The third useful point is that this 14th century building expressed the essence of a modern city. How this could be so? The presence of the past in modern architecture and urbanism is a topic to which we will return below.

The Swiss Pavilion was not Le Corbusier's only project that included upward oriented cells. A precedent for this solution, which might otherwise be seen as merely expedient (adding five more student rooms without ruining the façade's proportions), can be seen in his Cité Universitaire student housing project of 1925 (Figs. 5, 6). I have cited part of the key passage already:

The student belongs to an age of protest against old Oxford; old Oxford is a fantasy ... What the student wants is a monk's cell, well lit and well heated, with a corner to gaze at the stars. He wants to be able to find ready-to-hand whatever he needs to play sports with his fellows. His cell should be as self-contained as possible. ${ }^{13}$

And what was true for one should be true for all, each should enjoy the same standard (ethically speaking), which was for Le Corbusier a measure of common expectation:

. . . all students are entitled to the same cell; it would be cruel if the cells of poor students were different from the cells of rich ones. So the problem is posed: university housing as caravanserai; each cell has its vestibule, its kitchen, its bathroom, its living room, its sleeping loft, and its roof garden. Walls isolate each. Everyone assembles on the adjacent playing fields or in the common rooms of shared service facilities. ${ }^{14}$ 
David Leatherbarrow

Le Corbusier.

Cité Universitaire, Paris, 1925.

5. Plan and section of cells.

From Euvre Complète, 1910-29.

6. Axonometric of cells.
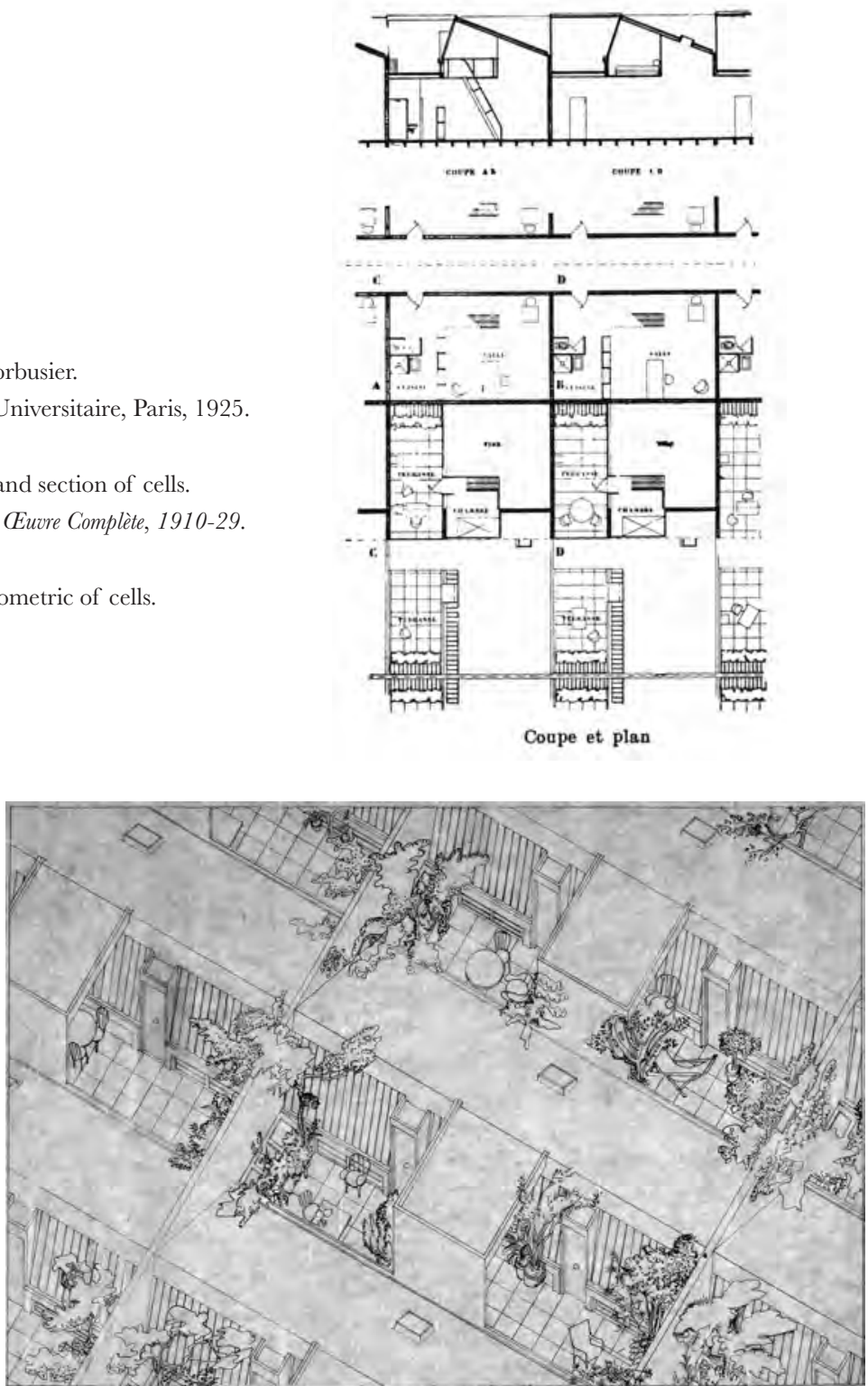
In this project, as in the villa-apartments of a few years earlier, the aim was to separately acknowledge and then integrate settings for individuals and the group, reconciling the individual with the collective. He often said that this particular reconciliation was the greatest challenge of both modern architecture and modern life. ${ }^{15}$ Assuming sports interested many of the student-monks, there were ample courts and playing fields. For the less athletically inclined there were the gardens in between the courts, and the closely cropped tree screens - as in French parks, or the gardens behind the rue de Rivoli - between the houses and the streets, under which students and friends could walk or read, alone or with others. The project was timely, for the University of Paris and the city had agreed in 1921 that the many students who came to the capital for study but could not find suitable or affordable housing needed new premises. The location for the new housing was in the southern part of the city, the land that was to form the site of the Cité Universitaire, of which Le Corbusier's Swiss Pavilion would be part.

Great care was also taken with the individual cell in his 1925 project. Each was to be no less complete than a monk's house at Ema, although smaller in size. The student cells were barely two-story. Yet, a raised sleeping loft provided a near equivalent to the Ema cell section and an open terrace substituted the monk's garden. Lastly, "gazing at the stars" oriented the student-monk to the wider horizon, as the passage window had done at Ema. Here, as with many of his projects, the axonometric view demonstrated the importance and role of the garden roof as the destination of movement through the accommodation. In each cell, as in the monastic precedents and his famous chambre de travail by the sea, isolation was decisive: "the cell should be as self-contained as possible." 16

In both the student housing and the Swiss Pavilion the importance of isolation was matched by the significance of self-sufficiency, or the degree of self-reliance that student housing could reasonably allow. A second little controversy that troubled the project for Swiss students can be used to illustrate this point - the matter of individual showers. 
Against the cost-saving aims of his client, who thought one set of common showers on every floor would be fine for students, Le Corbusier insisted that each should have a shower in his or her room. For a man who practiced a rather ascetic way of living, providing a sense of luxury was clearly not the aim. Each room was also to have two closets, a sink, and the sitting/ study/sleeping room (containing a bed, desk, and shelves) facing a fullyglazed southern wall. Though all glass, the window wall was sub-divided into translucent panes below the level of the desk and transparent panes above. His argument in defense of the individual shower, and by implication of personal hygiene was as follows:

'Senator Honnorat has asked us urgently, and on several occasions, to remove the showers from each room, replacing them with a common shower room somewhere within the building. But we think it is not extravagant to install one shower per room.' If this still seemed an overindulgence, they could have the 'showers with cold water only. ${ }^{17}$

Here, too, there was a precedent in the traditional model to which he had previously referred. Water was on hand in both the monastic cells and gardens at Ema. In his sketches he took care to draw and label to two water basins, one with a bucket and chain for drinking and washing, another for irrigating the plants.

That he personally identified with this need for contemplative privacy, and the well-being of both mind and body, can be inferred from the quotations adduced thus far. But a line from the speech he gave in London, on the occasion of his receipt of the AIA Gold Medal confirms his identification with the life of the student-monk. After the customary allusions to all of the mistreatments he had received in his career, he explained the way he wanted to be seen, or had seen himself:

I feel a bit like a puncher of metro tickets. Thinking what I see and seeing everything in architecture means leading a dog's life! There are problems before 
us. Values change daily. The world explodes. And I, for one, am still living a little in the skin of a student. ${ }^{18}$

Two interpretations of this self-portrait seem sensible. The first is that even in his advanced years, having accomplished so much - so many buildings, books, and works of art - he felt that there was still more to learn, that more study was necessary, that he hadn't yet graduated. No doubt there is good sense to this, but one must also remember that throughout his life he insisted on the rejection of all things "academic."19 Moreover, the expression he chose is striking: "the skin" of the student, la peau d'un etudiant. Why this way of phrasing it? Might it be that even in the evening of his life he had not given up the student's way of life, the self-imposed distance from family and home, the making due with less, and the acceptance of a regimen and rule, all for the sake of new beginnings, growing out of critique but leading to new associations, founded on common interests and shared goals? If so, it would be because he saw the life of the student and of a monk to have very similar profiles, each historically grounded..$^{20}$

\section{Monastig TyPes}

Although the Carthusian monastery to which we, following Le Corbusier, have repeatedly referred was built centuries before the modern period, the type's history is much more ancient. Each of the chapters that narrate the story of monasticism follows the pattern set by the Desert Fathers in remote antiquity and was exemplified by the lives of figures such as St. Anthony (251-356), often said to be the founder of the western monastic life style, Pachomios (292-348), whose monastic settlement was among the first in the west, and John Cassian or John the Ascetic (360-435), whose writings provided the basis for many of the subsequent Rules, including the one that is today the most famous, Benedict's. The pattern these and other early figures established was simple: first, repudiation and rejection of contemporary 
culture, prompted by new awareness of primary realities (which echoes rather exactly Le Corbusier's "modernist" stance); second, retreat in order to recover experiences taken to be fundamental, which with the soul seeks realignment (also a Corbusian procedure and aim); and third, re-articulation of a new way of life (albeit mimetic) in the form of schedules, regimens, and rules that govern (thanks to the abbot's oversight) all manner of spiritual, social and spatial practice. Each time this sequence was reenacted the tension between isolation and fellowship re-emerged, the spatial structure of which determined the distances and connections between the individual cells of a monastery and its shared cloister. Each of leaders of the later ordersBenedict, of the Benedictines; Bruno, of the Carthusians; Bernard, of the Cistercians; Francis, of the Franciscans; Dominic, of the Dominicans; and Clare, of the Poor Clares - tried to restore the complementarity of personal and communal life, according to their own sense of the Rule, governing conditions that were both spiritual and material.

Perhaps the most explicit architectural manifestation of the tension or complementarity between the spaces of solitude and fellowship is the Charterhouse type, Le Corbusier's favourite, as we have seen (Fig. 7). The origins are well documented. St. Bruno (1030-1101) played the role of founder. He was born in Cologne and educated at Reims, where he became head of the city's great episcopal school and friend of Pope Urban 11, whom he had taught there. He also had contact with Robert of Molesme, who helped form the Cistercian Order. The intrigues and disappointments of his administrative life seem to have strengthened his resolve to abandon all these involvements, but instead of following the newly formed Cistercian way with Robert, after a period of wandering in the forests and marshes of eastern France, he won support from the Bishop of Grenoble, who apparently anticipated the request, having had a dream about Bruno and his small group of followers standing in an uninhabited clearing under a crown of seven stars. The Bishop took them to a rather wild spot in the Alps called Chartreuse, a valley surrounded by precipitous slopes of an inhospitable and inaccessible limestone massif, covered most of the year with snow (Fig. 8). 


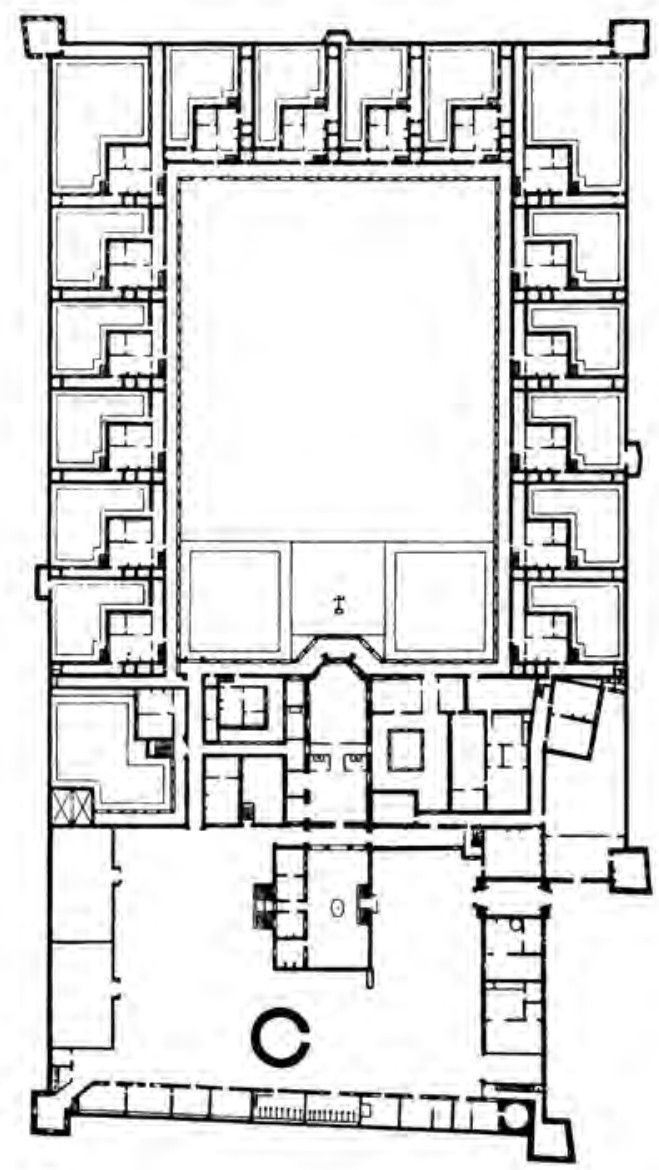

7. Carthusian Monastery, Clermont. Plan.

From Viollet-le-Duc,

Dictionnaire raisonné de l'architecture

française du XIe du XVIe siècle (Paris:

A. Morel, 1875), ill. 27. 
David Leatherbarrow

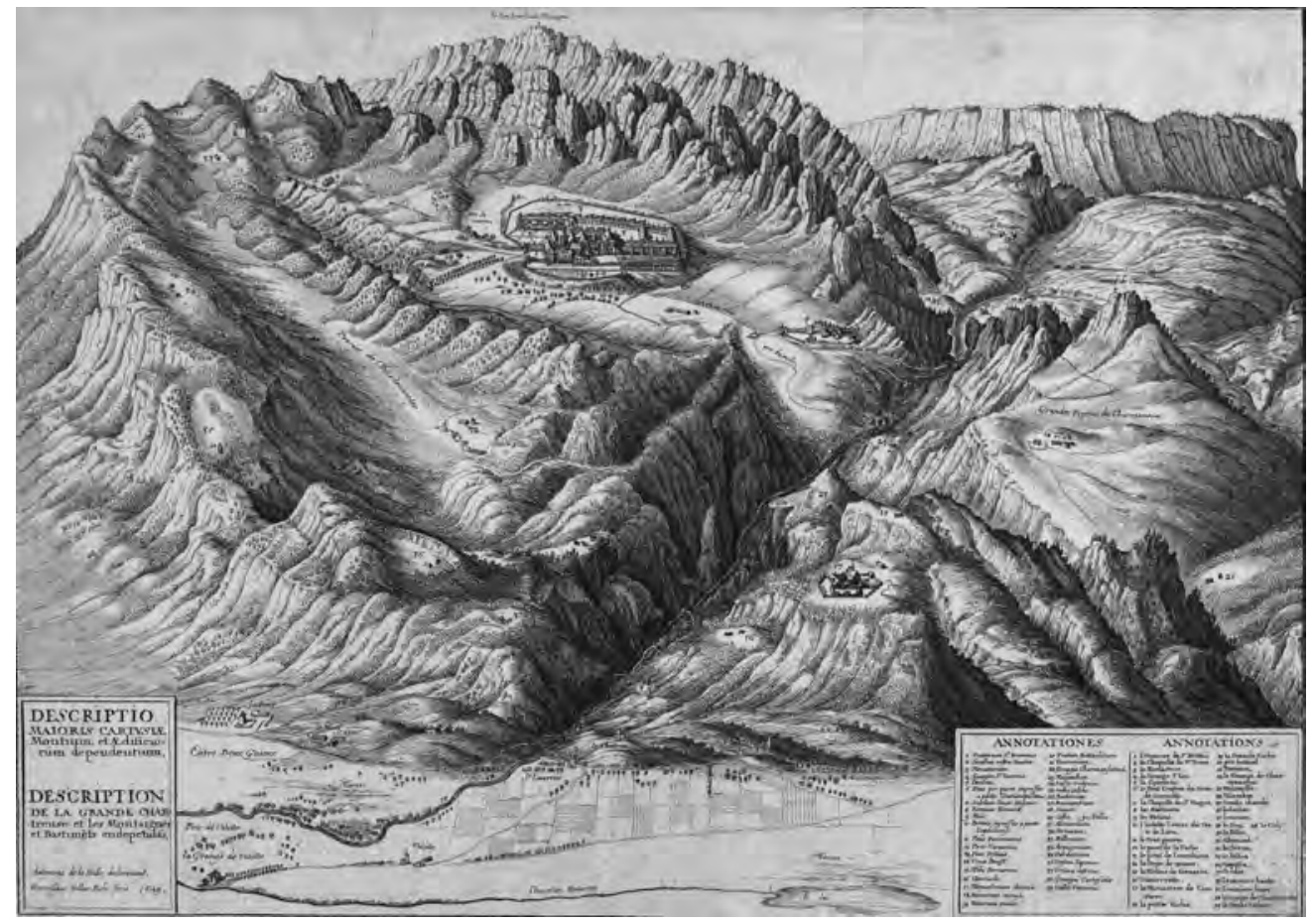

8. Carthusian monastery (La Grande

Chartreuse), Grenoble, ca. 1084.

Aerial view, Wenceslaus Hollar, 1649. 
The heat and sands that were so liked by the Desert Fathers couldn't be found there, but the place was similarly desolate. In that spot Bruno and his followers established the first Charterhouse monastery, as well as the Carthusian way of living.

The simplest way of describing this type way of living is to say that Carthusians combined the two fundamental impulses of the entire tradition: ermitical and cenobitic life. They wanted nothing more than solitude, but recognized the need for and benefit of fellowship. Acknowledging this double demand, Bruno gave each of the twelve their own little house, but demanded that they all appear in the shared spaces - the church, chapter house, and refectory - at the appointed hour, according to a schedule that was at once diurnal, seasonal, and liturgical. Cell is probably not the right word for such a house. It was twice removed from the shared cloister, first by the cloister walk and second by an internal passage that often contained a stair. Within the unit there were several settings: an anteroom (the only one that was heated), a bedroom large enough for a table or two, an adjoining room used for work, a small larder, and long corridor that led to the latrine. But that was not all. Each house had its own garden or yard for work, as we have seen in Le Corbusier's studies. It was three or four times larger than the house and sheltered behind an enclosing wall. Why the garden or yard? Each monk was to practice a skill that would be of use to the monastery as a whole.

Seen as a whole ensemble, the configuration acknowledged the principle and reciprocity of ora et labora. The results of work in the yard or garden would be enjoyed in the refectory of course, but also places like the scriptorium or armarium. In addition to the individual and key shared spaces (the cloister of houses wrapping around the cemetery, and the church, chapter house, refectory, and prior's house), there was a set of spaces, generally on the west side, for the lay brothers, the conversi and donati, who not only managed many of the physical needs of the monastery but served as a protective interface between their secluded enclosure and the world beyond. Within the walls of the monastery, however, the equilibrium between spaces for individual and collective life was carefully constructed and controlled. 
As we have seen, an exceptionally enthusiastic appreciation of this balance was offered nine centuries after Bruno's work by Le Corbusier. To Charles L'Eplattenier he confessed: "I would like to live all my life in what they call their cells. It is the [perfect] solution to the working man's house, type unique or rather an earthly paradise." "From this moment on I saw the two terms, individual and collectivity, as inseparable." ${ }^{21}$ In Marseilles Block he wrote similarly: "The Chartreuse d'Ema near Florence made me conscious of the harmony which results from the interplay of individual and collective life when each reacts favourably upon the others. Individual and collectivity comprehended as fundamental dualism." ${ }^{22}$ Insofar as the key problem for architecture and urbanism in the modern world was reconciling these two, the historical monastery was an entirely relevant point of reference.

\section{A Modern Angient}

For Le Corbusier, then, designs that could be called modern design were hardly free from historical associations, nor of indications of ancient precedents. As we observed at the outset: movement forward was prompted by movement backward, paradoxical though that double movement may seem. Yet, the monastic tradition was not the only context of historical reference for Le Corbusier, there were others. As is well known, he turned his attention toward ancient Greece and Rome, too; particularly when establishing the foundation for the new architecture in his most widely read publication: the Parthenon was famously compared to an automobile. References such as this could be multiplied at great length. He seems to have sustained a steady conversation with Michelangelo. And his discussion with vernacular traditions occupied him at great length.

Nor was Le Corbusier alone in this attention to ancient precedents and beginnings. Figures such as Adolf Loos, Richard Neutra, and Frank Lloyd Wright defined what they meant by modern architecture by referring to native precedents. Loos, for example, once said that he was a modern 
architect who built in the manner of the ancients. ${ }^{23}$ Richard Neutra's early books, Wie Baut America (1927) and Amerika (1930) framed their studies of modern construction with allusions to early American building traditionspueblo settlements of the Southwest in the first book, and these plus a circus tent in the second. This retreat-in-order-to-advance also occurred in Latin American countries, where designers believed that a return to their culture's radical foundations would provide the modern movement with a secure foundation. It is not inaccurate to say that modernism (resulting from social and cultural modernization) in this part of America preceded its importation from Europe. Consider the search for a Mexican architecture in the writings and work of figures like Juan O'Gorman, Max Cetto, and Luis Barragán, or, further south, in Brazil, Lúcio Costa's longstanding preoccupation with vernacular forms. Considering Costa's Missiões project (Museu em São Miguel), one cannot say in any decisive way where its historical and modern elements begin and end (Fig. 9).

Advances in modern architecture - particularly Le Corbusier's modern architecture - always depended on "conversations" with predecessors. Rarely were they viva voce, of course; they were instead asymmetrical, because the past, having passed, could not answer back. Yet silence did not prevent significance. For architects with non-dogmatic minds history's silence seems to have invited unending inquiry. Who among the moderns that still interest us today did not say both yes and no to work from the past? When one observes unbroken continuity of the modern tradition throughout the twentieth and into the twenty first centuries, one views a history that absorbed other traditions, having been neither initiated nor broken by them. Contemporary modern architecture is only the most recent example of this approach, meaning that it remains, as Habermas observed years ago, "an unfinished project." ${ }^{24}$

New worlds resulting from projects attuned to modern realities were envisaged, but they were rarely imagined to be wholly new, nor thought to be the responsibility of single designers. Adhesions to pre-existing conditions were seen as inevitable when actual sites, programs, materials, and builders 
were used as instruments of project realization. Furthermore, just as projects could not free themselves from inherited culture, they were rarely, if ever, realized in full. Non-finality came to be seen as the norm rather than the exception.

The coordination between a project and its historically structured location took a number of different forms in the built work of the modern period. The most obvious sort of connection was visual: the site presented itself through a series of views, around the building and from within it. The project's location was also understood dynamically, which is to say as a play of environmental forces; particularly, light, wind, and temperature. Design and construction entered into this play, into its sequences, transformations, and variations. This, too, is historical; one could say the site's natural history. Patterns could be discerned - days and seasons, for example - but the key principle was alteration, the outcome of which was development or deterioration. Further, simple and fundamental topics of spatial order, orientation for example, were conferred upon new buildings rather than constituted by them. This was especially the case with urban projectsLe Corbusier urban villas for example, or the Salvation Army building. Engagement with these "historical" conditions did not restrict invention but sustained it. Reversals of typical patterns of site development discovered unforeseen possibilities, thanks to attention to the project's location.

What was true for a building's siting was also true for its construction: conditions and techniques that arose in the past remained useful in the present. The more we learn about the actual construction of the buildings of the "heroic" period of modern architecture the more we see that later historians have been more dogmatic about materials and methods of construction than the architects themselves. No doubt the architects themselves partially initiated the familiar - if now-discredited - story about "modern" materials (steel, concrete, and glass) and "modern" means of construction (standardization, prefabrication and dry assembly) determining the "evolution" of modernism. Yet, the apologists went much further than the designers, in some cases to the point of obscuring the subject matter of 
Le Gorbusier: A Modern Monk
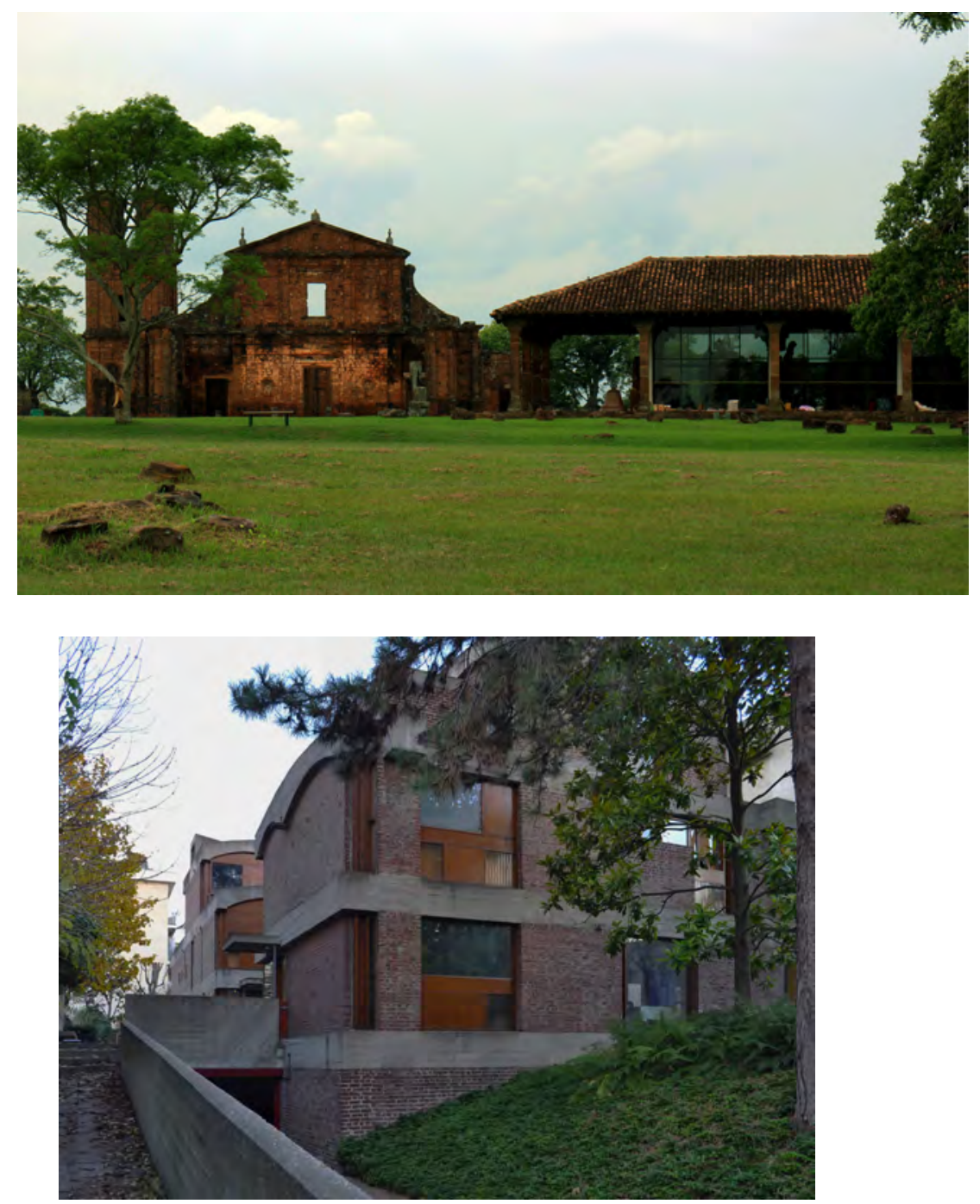

9. Lúcio Costa.

Museu das Missões

(Museum in São Miguel), Brazil, 1940. View.

10. Maisons Jaoul, Paris, 1951-56. 
their descriptions - the buildings themselves. Less polemical studies of the buildings of these years have shown that the actual construction of these works was often impure, that materials used for centuries were still used in the 1920s and 30s in combination with so-called "modern" materials, and that site work was both dry and wet, which is to say, factory made and made to look that way, or standardized and shaped on site for particular application. This was the case for Le Corbusier as early as the Loi Loucheur project. Vivid cases of wet and dry construction include the Villa Mandrot and Maisons Jaoul (Fig. 10). Hybridity was the norm, even when simplicity was claimed. Similarly, craft work was required even when elements that had been massproduced were installed. In some cases the complexities and compromises of the solutions were concealed, as if the project's hypothesis had to be saved at all costs. But in more cases the transformations that resulted from the use of available or affordable materials and methods led to new dimensions of significance and suitability. A simple, pure, or self-evidently modern way of building was far less important than careful attunement to ways of livingpatterns that were, of course, of their time.

The buildings of the modern period - chief among them Le Corbusier's - were designed and built to accommodate and express ways of living that were partly modern and partly traditional. What we have argued about monastic modernism is only one instance of this sense of the modern work. Possibilities were projected of course, patterns of life that might be present and may have occurred in the past; but ways of living nonetheless. The fact that these buildings acknowledged the continuity of ways of living, the hybridity of building practices, and the dependence of interior on site conditions suggests that another sense of the architectural project had force in these years: modern because historical. 


\section{Notes}

1 Le Corbusier, Le Corbusier Talks With Students, [1943] trans. Pierre Chase (New York: Orion Press, 1961), 34 .

2 Observations and arguments I will set out in this study elaborate points developed in a forthcoming book I have co-authored with Richard Wesley, Three Cultural Ecologies in the Architecture of Frank Lloyd Wright and Le Corbusier (London: Routledge, 2017).

3 Le Corbusier, Towards an Architecture, [1928] trans. John Goodman (Los Angeles: Getty, 2007), 286.

4 Le Corbusier, Unités d'habitation de grandeur conforme (Paris, April 1, 1957). FLC U3 07176.

5 The history of this little controversy, as well as that of the entire project is beautifully set out in Ivan Zaknic, Le Corbusier - Pavillon Suisse. The Biography of a Building (Basel, Boston, Berlin: Birkhäuser, 2004).

6 In point of fact, Le Corbusier had known of this larger number, what changed mid-project was the client's insistence that the increase be accommodated with the same amenities, particularly, an outward, not upward view to the open landscape.

7 In several drawings there was, however, a façade opening for the director's rooms.

8 Le Corbusier to Mr. the Senator Honnorat, President of Cité Universitaire, translated and cited in Zaknic, Pavillon Suisse, 193-195; our italics.

9 Zaknic, Pavillon Suisse, 193.

10 Different names can confuse allusions to this monastery. Sometimes it is called the Certosa di Firenzi, due to its proximity to that city. It might also be called the Certosa di Ema, or the Certosa del Galluzzo, as it is known more locally, because it is closer to that village than Florence. Ema is a small tributary to the River Arno. Thus a fourth name in French is Chartreuse du Val d'Ema. Le Corbusier abbreviated this last name, but retained the allusion to the river.

11 Le Corbusier. "A Dwelling at Human Scale," Precisions on the Present State of Architecture and City Planning, [1930] trans. Edith Schreiber Aujame (Cambridge, Mass.: MIT Press, 1991), 91-92.

12 Le Corbusier, interview with Jean Gallotti, in "The Shape of Tomorrow's Europe," trans. into Czech by J. Mala, "Tvář zitřejš́ Evropy." Kvart: sbornik poesie a vědy. (1945) [Quart: Proceedings of poetry and science]: 128-130.

13 Le Corbusier, Towards an Architecture, 286; my italics.

14 Ibid.; translation slightly modified. 


\section{David Leatherbarkow}

15 The first decades of the 20th century had witnessed a fundamental crisis, he thought, the individual against the collective, a crisis that had to be overcome through whatever means possible, for each was an absurd alternative. The isolated individual, even if genius, would inevitably lead a partial, broken life, and the mass man, even if familiar, would continually suffer anonymity. Throughout his work and life Le Corbusier sought an alternative, a coupling of people and places that would achieve a state of equilibrium, or, as suggested in 1960, harmony. See: Le Corbusier, L'Atelier de la recherché patiente/Mein Werk (Stuttgart: Hatje, 1960); Creation is a Patient Search, trans. James Palmes (New York: Frederick A. Praeger, 1960), 65.

16 Ibid., Towards an Architecture.

17 Zaknic, Pavillon Suisse, 151.

18 Le Corbusier, 1961 AIA Gold Medal acceptance speech; see "Corbu," Time Magazine (May 5, 1961): 60-70. Also: Jean-Jacques Duval, “Le Corbusier parle...et écrit,” Spazio e Societa 8, no. 29 (March 1985): 56-57.

19 See, for example, the rejection of academic thinking in Precisions. The first lecture was called: "To Free Oneself Entirely of Academic Thinking." Precisions, 23. A more emphatic denunciation occurs in the middle of the lecture: "The declaration of faith of academism is no more than a mirage; it is a lie; it is the danger of our time." Ibid., 25.

20 Of course college and university life emerged historically from monastic institutions - the buildings, the social organization, and the way of life, albeit secularized. The theme of making due with less in Le Corbusier's work and modern, secular monasticism, has been studied recently in: Pier Vittorio Aureli, Less is Enough: On Architecture and Asceticism (London: Strelka Press, 2103).

21 Le Corbusier to Charles L'Eplattenier, 19 September 1907. FLC E2(12)9; Le Corbusier, Unité d'habitation de Marseilles (Paris: Édition Le Point, 1950), 35.

22 Le Corbusier, The Marseilles Block, [1950] trans. Geoffrey Sinsbury (London: Harvill Press, 1953), 45.

23 Loos wrote: "I am a modern architect because I build in the manner of the ancient Viennese." See Adolf Loos, "Eine zuschrift," [1910] Trotzdem (Vienna: George Prachner, 1982), 111 . In this instance, as in so many others in the modern period, the new architecture distinguished itself from the recent by returning to even older ideas and elements, those thought to be fundamental.

24 Jürgen Habermas, "Modernity-An Incomplete Project," [1980] in Hal Foster, ed., The AntiAesthetic (Port Townsend: Bay Press, 1983), 3-15. 